кандидат психологічних наук, доцент

(Тернопільський національний економічний університет)

\title{
СТРУКТУРА ФУНДАМЕНТАЛІЗАЦІЇ ПІДГОТОВКИ МАЙБУТНІХ СОЦІАЛЬИХ ПРАЦІВНИКІВ ДО ПРОФЕСІЙНОї ДІЯЛЬНОСТІ
}

У статті проаналізована структура фундаменталізації професійної освіти майбутніх сочіальних працівників на змістовно-організаційному і технологічному рівнях. Обгрунтовано наведені головні функиії, щзо виконує фундаменталізація професійної освіти. Розкрито важливі напрямки фундаменталізації професійної освіти, щчо засадничо направлені на формування структури системи фундаменталізачї професійної підготовки майбутніх сочүіальних працівників.

Ключові слова: фундаменталізація професійної підготовки, структура фундаменталізації освіти, майбутній соціальний працівник, професіоналізм фахівия.

Постановка проблеми. Нині в розуміннях науковців спостерігається неузгодженість щодо розв'язання проблем фундаменталізації професійної підготовки, оскільки цей процес відбувається доволі повільно та, незважаючи на загальнотеоретичні засади, є специфічним для різних напрямів підготовки майбутніх фахівців. Запровадження фундаменталізації професійної підготовки у вищих навчальних закладах допомогло б студентам різних соціогуманітарних спеціальностей творчо підходити до професійної діяльності в майбутньому та викладачам результативно вирішувати протиріччя між професійною освітою і вузькопрактичною професійно-традиційною підготовкою в процесі вивчення навчальних дисциплін. Однією з актуальних проблем сучасної університетської професійної освіти $\epsilon$ розв'язання суперечності між фундаменталізацією навчального процесу та спрямованістю знань майбутніх фахівців відповідно до професійної діяльності [1: 282-284]. Тому важливою залишається проблема охарактеризування структури фундаменталізації професійної підготовки майбутніх соціальних працівників у вищій школі.

Аналіз основних досліджень i публікацій із зазначеної проблеми. Фундаменталізація університетської освіти на сучасному етапі професійної підготовки фахівців соціогуманітарних спеціальностей розробляється в різних аспектах. Так, сутність фундаменталізації освіти обгрунтована в філософських i педагогічних працях І. Бардус, Н. Бідюка, О. Бондаренка, Л. Зоріна, М. Карлова, Б. Камінського, С. Клепко, Т. Кобильника, І. Козловської, Е. Лузик, В. Нестеренка, Л. Пуховської, 3. Решетової, С. Романової, В. Стешенка, О. Школи.

Методологічну основу фундаменталізації професійної освіти складають антропологічний, герменевтичний, діяльнісний, індивідуальний, культурологічний, особистісно-орієнтований, онтологічний, парадигмальний, системний, цілісний та ін. підходи, які направлені на проектування, конструювання, моделювання, технологізацію, інтеграцію та організацію процесів фундаменталізації навчання (Н. Бідюк, Г. Васьківська, Т. Вдовичин, М. Дмитриченко, Б. Камінський, С. Клепко, I. Козловська, Е. Лузик, І. Мельничук, Л. Пуховська, С. Романова, Л. Романишина, Я. Фруктова та ін.).

Вивченню фундаменталізації вищої освіти за університетського навчання присвячені роботи С. Гончаренка, I. Гавриляк, М. Жалдака, С. Семерікова, С. Сисоєвої, Я. Фруктової, Г. Шатковської. Описують фундаменталізацію професійної підготовки майбутніх фахівців у вимірі європейського освітнього простору М. Дмитриченко, О. Русановський, В. Сидоренко, Г. Терещук.

Разом 3 тим, незважаючи на наявність системної роботи сучасних науковців щодо розробки теоретичних та методологічних основ фундаменталізації професійної освіти [2-5], у яких важлива роль відводиться проектуванню змісту професійної освіти та іiі взаємозв'язку з фундаменталізацією навчального процесу, дидактичний аспект структури фундаменталізації професійної підготовки майбутніх соціальних працівників розроблений недостатньо.

Метою статті $є$ визначення та схарактеризування системи фундаменталізації професійної освітньої підготовки майбутніх соціальних працівників на рівні сучасного університету відповідно до змістовноорганізаційного та інтеграційно-технологічного рівнів фундаменталізації професійної освіти.

Виклад основного матеріалу 3 обгрунтуванням отриманих наукових результатів. Соціальноекономічний розвиток України в напрямку "постіндустріального суспільства" призвів до того, що змінилася структура, зміст, технології, засоби професійної діяльності всіх соціогуманітарних сфер суспільства. Для фахової діяльності соціального працівника нині характерні диверсифікація, варіативність, диференціація, індивідуалізації тощо. Вона з кожним днем стає все більш наукомісткою, інтелектуальною, творчою, інтеграційною та технологічною [6:2-5]. Тому очевидно, що суб'єкти майбутньої професійної діяльності повинні досконало володіти методологією соціальної роботи, 
мати сформовані вміння i навички впровадження здобутого у вищому навчальному закладі фундаментального знання в діяльнісний процес, вміти компетентнісно проводити дослідження з будь якої фахової проблеми та нести соціальну й особистісну відповідальність за свої професійні вчинки та дії. Зазначені найважливіші професійні компоненти ефективної діяльності майбутніх соціальних працівників тісно пов'язані 3 необхідністю глибинних перетворень теоретико-методологічних основ загальнонаукової і фахової підготовки студентів за університетського навчання [7: 55-60]. Дуже цінним, на нашу думку, $\epsilon$ перехід від змістовного оволодіння професійними знаннями до вміння їх використовувати у професійній діяльності згідно теоретико-методологічних та інноваційнотехнологічних освітніх засад.

Цю найважливішу професійну проблему повинна вирішити фундаменталізація професійної освіти на змістовно-організаційному і технологічному рівнях. Такий підхід відповідає новій гуманістичній, суб'єктно-ментальній (світоглядній) парадигмі професійної освіти, яка за своєю спрямованістю тісно пов'язана 3 фахово-особистісним розвитком майбутнього соціального працівника як професіонала [8: 2-4].

Задана освітня ситуація актуалізує не лише проблему фундаменталізації навчального процесу, а й проблему фундаменталізації особистості в процесі професійної освіти. На переконання науковця I. Бардус фундаменталізація освіти тісно пов'язана із розумінням та вивченням концептуальних законів світу, фундаментальних смислів буття людини в соціумі [2: 8-10]. При цьому основна роль відводиться знанням, які й уможливлюють вироблення шляхів і методів пізнання сутності світу [4: 112-116]. Основою професійного буття за соціально-культурної традиції $\epsilon$ професійне служіння, що слугує засадничим підгрунтям у формуванні менталітету майбутнього фахівця та яке й визначає в майбутньому змістову спрямованість професійної діяльності. Як наслідок, завданням фундаменталізації особистості в процесі професійної освіти є сприяння становленню майбутнього фахівця як суб'єкта професійного буття, як особистості, як індивідуальності відповідно до професійної "Я-концепції". Розв'язання цього складного завдання допомагає викладачу на заняттях формувати в кожного студента професійну ідентичність.

При окресленому підході до стратегії фундаменталізації професійної підготовки майбутніх соціальних працівників фундаменталізація професійно спрямованого навчання і фундаменталізація особистості майбутнього фахівця виступають інтегрованими освітніми процесами. В результаті зазначеної інтеграції вибудовується виважена методологічно-змістовна основа, яка слугує дієвим підгрунтям у розв'язанні сучасних освітніх завдань щодо встановлення компетентнісного професіоналізму [9: 2-4]. Такий підхід до навчання відповідає сучасній направленості розвитку професійної підготовки, оскільки фундаменталізація навчального процесу - це не тільки нова якість змістового наповнення професійно-зорієнтованих дисциплін, а й неодмінна умова для подальшої професійної освіти впродовж життя та цілісного сприйняття світу загалом [3; 8].

Фундаменталізація професійної освіти забезпечує еволюційно-інноваційну динаміку професійного розвитку та пов'язана з формуванням методологічної культури майбутніх соціальних працівників, так як зміст освіти стає більш професійним і творчим. За такого навчання формуються універсальні навички, які впливають на створення сприятливих умов для вільної конкурентоспроможності дипломованих фахівців соціальної роботи на ринку праці [10: 33-35].

Науковці С. Гончаренко та О. Семеріков вказують на те, що нині у час професійних інновацій знання, отримані за фундаменталізації професійної підготовки практично без усякої модифікації, є одночасно і професійними, оскільки саме фундаменталізація забезпечує перехід від підтримуючого навчання до випереджаючого [6; 9].

Отже, фундаменталізація професійної освіти за сучасних умов функціонування університетської освіти виконує дві головні функції:

- формує особистісні моделі професійного буття на основі професійного менталітету;

- генерує в студентів системне, цілісне, теоретико-методологічне знання, яке неминуче потрібне для розвитку результативної професійної діяльності відповідно до об'єктивної ситуації та суб'єктивної необхідності іiі адресного проектування та впровадження сучасних інтегрованих соціогуманітарних технологій.

Дані функції слугують можливістю та умовою зреалізування майбутнім соціальним працівником власного теоретичного, практичного, наочно-дієвого, наочно-образного, формально-логічного, творчого, критичного, дискурсивного, інтуїтивного та ін. мислення, сформованого в процесі фундаменталізації професійної підготовки.

Водночас процес фундаменталізації професійної діяльності та фундаменталізації особистості соціального працівника вибудовується на декількох важливих положеннях до фундаменталізації професійної освіти, які засадничо направлені на формування структуру системи фундаменталізації професійної освіти: 
- $\quad$ Фундаменталізація професійно-освітньої підготовки майбутнього фахівця є випереджаючою в контексті розвитку професіоналізму діяльності та професіоналізму особистості, у якій особистісний ресурс розуміється як готовність соціального працівника змінювати бачення про себе відповідно до зовнішнього сприйняття інформації про "Я-реальне" [8].

- Фундаменталізація професійної освіти виникає на основі бінарного принципу діалектичної єдності фундаменталізації і професіоналізації як освітньої цілісності. Цей принцип характеризує якість професійної освіти, що випливає із змістового наповнення навчальних дисциплін, представлених загальноосвітньою, методологічною, теоретичною, інтеграційно-технологічною та спеціальною підготовками. Діалектична єдність цих компонентів передбачає фундаменталізацією кожного 3 них [5].

- $\quad$ Фундаменталізація освіти забезпечується доцільним поєднанням онтологічного, гносеологічного та аксіологічного підходів до підготовки майбутніх соціальних працівників [7].

- Фундаменталізація професійної підготовки стосується всіх елементів та складових освіти: цілей, змісту, процесу, методів, засобів, форм, результатів тощо. Однак провідна роль відводиться фундаменталізації освітнього змісту навчальних дисциплін [3].

- Фундаменталізація освіти не суперечить предметній основі освіти, оскільки передбачає відображення у навчальних предметах загального, особливого і одиничного, i, водночас, продукує системне бачення предмета з позицій загального і цілого [4].

- Фундаменталізація професійної освіти є дієвим засобом формування професійного буття особистості на засадах концептуалізації, методологізації професійної діяльності та розвитку цієї діяльності за допомогою впровадження інтеграційно-інноваційних технологій [9].

Запропоновані концептуальні положення дозволяють визначити структуру фундаменталізації професійної освітньої підготовки майбутніх соціальних працівників на рівні сучасного університету європейського зразка. Дана структура включає:

- формування в майбутніх соціальних працівників у системі професійної підготовки вищого навчального закладу мотиваційної готовності до внутрішньої реалізації стратегії фундаменталізації освіти на основі її інтеріоризації як особистісної цінності фахівця;

- $\quad$ адаптацію сучасної науково-методологічної концепції фундаменталізації професійної освіти та ії цілісної теорії до освітнього простору, вітакультурного середовища та системи університетського навчання;

- розробку та зреалізування основної моделі фундаменталізації професійно-зорієнтованої освіти у вищій школі, що включає мету та завдання фундаменталізації, фундаменталізацію змістового наповнення навчальних дисциплін за напрямком професійної підготовки "Соціальна робота", інтеграцію інноваційних технологій фундаменталізації професійної підготовки майбутніх соціальних працівників, а також методи, прийоми і засоби фундаменталізації навчального процесу.

Можливість реалізації системи фундаменталізації професійної освітньої підготовки майбутніх фахівців соціономічних професій забезпечується наявністю їі сучасної дидактичної інтерпретації.

Висновки та перспективи подальшого дослідження проблеми. Структура фундаменталізації професійної підготовки соціальних працівників окреслює межі забезпечення необхідної базової фаховозорієнтованої підготовки для здійснення в майбутньому ефективної професійної діяльності і для продовження професійної підготовки впродовж життя згідно вимог часу. Важлива роль у структурі відводиться принципу фундаменталізації, що направлений на оволодіння високим рівнем професійної компетентності та передбачає повноту набору соціогуманітарних дисциплін, котрі забезпечують базову підготовку в єдності 3 професійною та спеціалізованою. Вибудувана таким чином структура фундаменталізації освіти $€$ важливою передумовою забезпечення безперервності та наступності професійної освіти й розглядається нами як явище, як принцип професійно-зорієнтованої освіти, як процес, що має власну дидактичну структуру та зміст і як цілісна теорія навчання.

Дидактична інтерпретація фундаменталізації професійної освіти, а саме структура та іiі змістове наповнення, слугуватиме перспективним напрямом нашого наступного дослідження.

\section{СПИСОК ВИКОРИСТАНИХ ДЖЕРЕЛ ТА ЛІТЕРАТУРИ}

1. Баранівський В. Ф. Компетентність і фундаменталізація освіти як сучасні парадигми розвитку вищої освіти / В. Ф. Баранівський // Вісник національного університету оборони України. - 2011. - Вип. 6. - С. $282-285$.

2. Бардус I. О. Філософські засади концепції фундаменталізації професійної підготовки майбутніх фахівців у галузі інформаційних технологій / І. О. Бардус// Проблеми інженерно-педагогічної освіти. - 2016. - № 5253. - C. 7-17.

3. Васьківська Г. Фундаменталізація змісту освіти у старшій школі : теорія і практика / Г. Васьківська // Рідна школа. - 2012. - № 3. - С. 25-30.

4. Ребуха Л. 3. Инновационные технологии в профессиональной подготовке будущих социальных работников / Л. 3. Ребуха // Теория и методика профессионального образования. - Минск : РИПО. - 2017. - Выпуск 4. Часть 1.- С. 112-117. 
5. Фруктова Я. С. Фундаменталізація змісту професійної освіти як сучасна педагогічна проблема / Я. С. Фруктова // 1025-річчя історії освіти в Україні: традиції, сучасність та перспективи: [зб. матер. міжнарод. наук. конф.]. - Київ (22 травня 2014 р.) - С. 310-316.

6. Семеріков С. О. Фундаменталізація навчання інформаційних дисциплін у вищій школі : [монографія] / С. О. Семеріков ; наук. ред. акад. АПН України, д. пед. н., проф. М. І. Жалдак. - Кривий Ріг : Мінерал ; К. : НПУ ім. М. П. Драгоманова, 2009. - 340 с.

7. Мельничук I. М. Філософсько-методологічні засади професійної підготовки майбутніх фахівців соціономічних професій / І. М. Мельничук // Медична освіта. - 2012. - № 3. - С. 55-60.

8. Ковтонюк М. М. Фундаменталізація освіти як необхідний чинник у системі професійної підготовки спеціаліста [Електронний ресурс] / М. М. Ковтонюк // Проблеми сучасної педагогічної освіти : педагогіка і психологія. - Кримський гуманітарний університет. - 2011. - Вип. 34. - Ч. 1. - С. 2-5. - Режим доступу : http://www.nbuv.gov.ua/portal/soc_gum/pspo/2011_34_1/Kovtonyuk.pdf.

9. Гончаренко С. У. Фундаменталізація освіти як дидактичний принцип / С. У. Гончаренко // Шлях освіти. 2008. - № 1. - С. 2-6.

10. Гавриляк I. С. Шляхи розвитку фундаменталізації змісту сучасної професійної освіти / I. С. Гавриляк // Вісник Черкаського національного університету імені Богдана Хмельницького. Серія : "Педагогічні науки". - Випуск № 24 (237). - Черкаси. - 2012. - С. 33-37.

\section{REFERENCES (TRANSLATED \& TRANSLITERATED)}

1. Baranivskyi V.F. Kompetentnist' i fundamentalizatsiia osvity yak suchasni paradyhmy rozvytku vyshchoi osvity [Competence and Fundamentalization of Education as Modern Paradigms of the Development of Higher Education] / V. F Baranivskyi // Visnyk natsional'noho universytetu oborony Ukrainy [Bulletin of the University of National Defense of Ukraine]. - 2011. - Vyp. 6. - S. 282-285.

2. Bardus I O. Filosofski zasady kontseptsii fundamentalizatsii profesiinoi pidhotovky maibutnikh fakhivtsiv u haluzi informatsiinykh tekhnolohii [Philosophical Principles of the Concept of Fundamentalization of Professional Training of Future Specialists in the Field of Information Technologies] // Problemy inzhenerno-pedahohichnoi osvity [Problems of Engineering-Pedagogical Education]. - 2016. - № 52-53. - S. 7-17.

3. Vaskivska H. Fundamentalizatsiia zmistu osvity u starshii shkoli: teoriia i praktyka [Fundamentalization of the Content of Education in High School : Theory and Practice] / H. Vaskivska // Ridna shkola [Native School]. - 2012. - № 3. - S. 25-30.

4. Rebukha L. Z. Innovatsionnyie tekhnolohii v professional'noi podhotovke budushchykh sotsyalnykh rabotnikov [Innovative Technologies in the Professional Training of Future Social Workers] / L. Z. Rebukha // Teoriia i metodyka professional'noho obrazovaniia [Theory and Methods of Professional Education]. - Minsk : RYPO. 2017. - Vypusk 4. - Chast' 1. - S. 112-117.

5. Fruktova Ya. S. Fundamentalizatsiia zmistu profesiinoi osvity yak suchasna pedahohichna problema [Fundamentalization of the Content of Professional Education as a Modern Pedagogical Problem] / Ya. S. Fruktova // 1025-richchia istorii osvity v Ukraini : tradytsii, suchasnist ta perspektyvy [1025th Anniversary of the History of Education in Ukraine : Traditions, Modernity and Future] : [zb. mater. mizhnarod. nauk. konf]. - Kyiv (22 travnia 2014 r.). - S. 310-316.

6. Semerikov S. O. Fundamentalizatsiia navchannia informatsiinykh dystsyplin u vyshchii shkoli [Fundamentalization of Teaching of Information Disciplines in High School] : [monohrafiia] / S. O. Semerikov ; nauk. red. akad. APN Ukrainy, d. ped. n., prof. M. I. Zhaldak. - Kryvyi Rih : Mineral ; K. : NPU im. M. P. Drahomanova, $2009 .-340$ s.

7. Melnychuk I. M. Filosofsko-metodolohichni zasady profesiinoi pidhotovky maibutnikh fakhivtsiv sotsionomichnykh profesii [Philosophical-Methodological Principles of Professional Training of Future Specialists of Socionomical Professions] / I. M. Melnychuk // Medychna osvita [Medical Education]. - 2012. - № 3. - S. 5560 .

8. Kovtoniuk M. M. Fundamentalizatsiia osvity yak neobkhidnyi chynnyk u systemi profesiinoi pidhotovky spetsialista [Fundamentalization of Education as a Necessary Factor in the System of Professional Training of an Expert] [Elektronnyi resurs] / M. M. Kovtoniuk // Problemy suchasnoi pedahohichnoi osvity : pedahohika i psykholohiia [Problems of Modern Pedagogical Education : Pedagogy and Psychology]. - Krymskyi humanitarnyi universytet. 2011. - $\quad$ Vyp. 34. - $\quad$ Ch. $1 . \quad-\quad$ S. 2-5. - Rezhym dostupu : http://www.nbuv.gov.ua/portal/soc_gum/pspo/2011_34_1/Kovtonyuk.pdf.

9. Honcharenko S. U. Fundamentalizatsiia osvity yak dydaktychnyi pryntsyp [Fundamentalization of Education as Didactic Principle] / S. U. Honcharenko // Shliakh osvity [The Way of Education]. - 2008. - № 1. - S. 2-6.

10. Havryliak I. S. Shliakhy rozvytku fundamentalizatsii zmistu suchasnoi profesiinoi osvity [Development Ways of Fundamentalization of the Content of Modern Professional Education] / I. S. Havryliak // Visnyk Cherkaskoho natsionalnoho universytetu imeni Bohdana Khmelnytskoho. Seriia: "Pedahohichni nauky" [Bulletin of the Cherkasy National University named after Bogdan Khmelnytsky. Series: "Pedagogical Sciences"]. - Vypusk № 24 (237). Cherkasy. - 2012. - S. 33-37.

\section{Ребуха Л. 3. Структура фундаментализации подготовки будущих социальных работников к профессиональной деятельности.}

В статье проанализирована структура фундаментализации профессионального образования будущих сочиальных работников на содержательно-организационном и технологическом уровнях. Обосновань приведенные главные функции, которые выполняет фундаментализация профессионального 
образования. Раскрыто важные направления фундаментализации профессионального образования, изначально направленные на формирование структуры системы фундаментализации профессиональной подготовки будущих социальных работников.

Ключевые слова: фундаментализация профессиональной подготовки, структура фундаментализаџии образования, будущий сочүиальньій работник, профессионализм специиалиста.

\section{Rebukha L. Z. Structure of Fundamentalization of Future Social Workers' Training for Professional Activities.}

The problem of modern university professional education in resolving the contradiction between the fundamentalization of the educational process and the direction of knowledge of future specialists in accordance with their professional activities is actualized in the article. The importance of transition from the proficiency of professional knowledge to the ability to use it in professional activity according to theoretical-methodological and innovative-technological educational principles is characterized.

The necessity of solving the problem of the fundamentalization of professional education at the contentorganizational and technological levels is substantiated, since this approach corresponds to the new humanistic and ideological paradigm of professional education. Approaches to the strategy of fundamentalization of the

professional training of future social workers are considered, which include the fundamentalization of professionally directed education and the fundamentalization of the personality of the future specialist and serve as integrated educational processes. The fundamentalization of the educational process is defined not only as a new quality of the content of professionally oriented disciplines, but also reflected as an indispensable condition for the holistic perception of the world and the further continuous professional education throughout life. It is noted that the fundamentalization of professional education carries out two main functions (forms personal models of professional life on the basis of professional mentality and generates a systematic, holistic,

theoretical - methodological knowledge for students which is inevitably necessary for the development of productive professional activity) and, accordingly, provides transition from supportive education to professionally-oriented.

Conceptual provisions, that allow determining the structure of fundamentalization of professional education of future social workers at the level of the modern university of the European model, are proposed. It is concluded that the structure of fundamentalization of professional training of social workers outlines the limits of providing the necessary basic professional-oriented training for the implementation of effective professional activities in the future.

Key words: fundamentalization of professional training, structure of fundamentalization of education, future social worker, professionalism of a specialist. 